\title{
The Right To Health In Indonesia Post Two Decades Of Reformation: Limited Progress, Uneven Distribution
}

\author{
Riana Mardila \\ Department of International Relation, Faculty of Social and Political science, UIN SyarifHidayatullah Jakarta
}

\begin{abstract}
The terms of 'right to health' is not so much popular compared to human rights. Most of the time, people more concern about the implementation of the right to health (i.e., national health insurance, healthcare, etc.) without knowing the concept of the right to health itself comprehensively. In Indonesia, if we look at Human Rights Watch (HRW) World Report, none of the recorded violations is particularly mentioning the violations of the right to health. It appears briefly two possibilities: is it the right to health that have not been aware of or has Indonesia fulfilled its obligation towards it, so Indonesia is free from such violation?
\end{abstract}

This research aims to discover the development of health rights in Indonesia after twenty years of Reformation. This research using qualitative methodstudy of literature. The structure will be divided into four segments: the introduction; the method that will explain the framework I use to guide the research; the result and discussion; and last is my conclusion. I conclude that first, the right to health is complex. Therefore, the approach to the realization should be from the multidimensional aspect. Second, after the Reformation, this paper agrees that Indonesia has acknowledged and developed its right to health that can be witnessed through some of its national programs. These programs are evidence that Indonesia put attention to this right even though imperfectness of the implementation cannot be denied as well. It also indicates that other stakeholders' role will help and catalyze such fulfillment if cooperating with the government.

Keywords: human rights, the right to health, right to health in Indonesia

\section{INTRODUCTION}

The terms of 'right to health' is not so much well known compared to human rights. Most of the time, people more concern about the implementation of the right to health (i.e., national health insurance, healthcare, etc.) without knowing the concept of the right to health itself comprehensively. It is not an odd phenomenon because even in global sphere right to health is being marginalized most of the time in most places of the world. Meanwhile, it is also a part of human rights.

In Indonesia particularly, if we look at Human Rights Watch (HRW) World Report [1], none of the recorded violations is directly mentioning the violations of the right to health. They are the violations of Indonesian government on freedom of religion, women's and girl's rights, Papua, sexual and gender identity, military reform and impunity, children's and disability rights, and last, the refugee and asylum seeker's rights. From such list, it appears that right to health in Indonesia has not often been discussed like other rights. The only thing that relates to the right to health in the list is the disability rights. Even though this list is not a fixed measurement, it indicates briefly two possibilities: is it the right to health that have not been aware of or has Indonesia fulfilled its obligation towards it, so Indonesia is free from such violation? These possibilities attract my attention to research how is the development of the right to health in Indonesia particularly since the democratic era, in which democratic countries are responsible for protecting human rights including the right to health in their countries and global sphere.

This article argues that Indonesia in the present day has indeed acknowledged the existence of the right to health and continuously attempt to fulfill its obligation based on ICESCR (International Covenant on Economic, Social, and Cultural Rights) and WHO's (World Health Organization) guidance. However, as the right to health is complex and interrelated, such attempt is still limited to some extent. Therefore, to say that Indonesian government has fulfilled all the obligation is hyperbole. Nonetheless, arguing that there has not been much development towards the right to health in Indonesia also undermines the efforts so far. In addition, small progress is still called as progress to be fair. 
This article is structured into four parts to reach my argument. First is the introduction where I state my point of interest and the way I structure the article to answer such interest. Second is the method that will explain the framework I use to guide the research. The third is the result and discussion in which my argument will be more explored. Last is my conclusion.

\section{METHOD}

This research starts with a grand question how is the development of the right to health in Indonesia particularly after two decades of Reformation. By 'development' this paper will assess it by measuring how far the obligations formulated by ICESCR (International Covenant on Economic, Social, and Cultural Rights) have been fulfilled by the Indonesian government. Even though this research is limited due to the word count, it will utilize the qualitative method emphasizing on the literature study.

To guide, this research is framed by two concepts on the right to health determined by the ICESCR and WHO. First is the concept of the right to health by WHO. Right to health was firstly introduced in the WHO Constitution as "the right to the highest attainable standard of health." It is said that "the most authoritative interpretation of the right to health is outlined in Article 12 of the ICESCR (International Covenant on Economic, Social, and Cultural Rights) which has been ratified by 145 countries as of May 2002" [2]. It is interpreted as an inclusive rights covering two indicators: timely health care and appropriate underlying determinants of health; such as "access to safe water and adequate sanitation, an adequate supply of safe food, nutrition and housing, healthy occupational and environmental conditions, and access to health-related education and information (sexual \& reproductive health)" [2]. Therefore, if this research discusses the right to health, then it refers to these two components.

The second concept used in this research is the core minimum obligations of the state that is initiated in ICESCR. It was initiated to measure the right to health in the states that ratified at least in the minimum level states can achieve. Indonesia eventually had ratified ICESCR in 2006 during President SoesiloBambangYudhoyono (Vol.2) which means the obligation should be soon fulfilled and it becomes a part of the national policy of Indonesia. It also means that the abandonment of it will be a violation of the government towards the citizens. Core minimum obligation includes [3]:
- $\quad$ "The right of access to health facilities, goods, and services on a non-discriminatory basis, especially for vulnerable or marginalized groups;

- Access to the minimum essential food which is nutritionally adequate and safe;

- Access to shelter, housing and sanitation and an adequate supply of safe drinking water;

- The provision of essential drugs;

- Equitable distribution of all health facilities, goods and services”.

From these five elements, they appear to be in line with the formulation of the right to health itself. And with these elements, the result assessments will be by matching and comparing these elements with the real facts happening in Indonesia.

\section{RESULTS AND DISCUSSION}

\section{The Development: A Limited Progress and Uneven Distribution}

This research argues that the development of the right to health in Indonesia after two decades of reformation is progressing. However, it is limited and uneven distribution. It still needs various evaluation and perfection. It can be analyzed by looking at first, the access to health facilities, goods, and services on a non-discriminatory basis, especially for vulnerable or marginalized groups. This research particularly calls the 'health facilities, goods, and services' as 'healthcare.' Healthcare in Indonesia can be said as progressing as we see the existence and evolution of national health insurance. This research considers national health insurance as important because it has the intention to provide and guarantee this first obligation albeit it is not the only way to provide the health care.

National health insurance in Indonesia has evolved long way before the Reformation. After the Soeharto regime, Indonesians still experienced the national health insurance that was established during Soeharto. They are Asuransi Kesehatan or ASKES (Health Insurance) organized by PT ASKES and later continued by PT JAMSOSTEK (Jaminan Sosial\& Tenaga Kerja: Social \& Labor Insurance) for civil servants, pensioners, veterans, and privates. For the poor, there were programs called JAMKESMAS (Jaminan Kesehatan Masyarakat: Community Health Insurance) and JAMKESDA (Jaminan Kesehatan Daerah: Regional Health Insurance) [4]. Nevertheless, these programs were considered as fragmented and thus in 2004, Indonesian government issued the ACT no. 40 about Sistem Jaminan Sosial Nasional 
(National Social Security System) including health (named as Jaminan Kesehatan Nasional (JKN): National Health Insurance). It is organized by Badan Penyelenggara Jaminan Sosial Kesehatan (BPJS Kesehatan: Institution of Social Health Insurance) and Badan Penyelenggara Jaminan Sosial Ketenagakerjaan (BPJS Ketenagakerjaan: Institution of Social Security Employment) which is still ongoing until the present day. The evolution of all of these insurances indicates that Indonesia has acknowledged the right to health and continuously attempt to fulfill it.

JKN is a mandatory health social insurance for Indonesian citizens, non-profit, and the benefits are comprehensive meaning that it does not depend on the paid fee unlike commercial insurance [4]. Its participants are all Indonesians and foreigners who have worked for more than six months in Indonesia, and they have paid the set due [4]. However, the participants are divided into two categories: Penerima Bantuan Iuran (PBI: Beneficiaries) or the poor and the one who is not PBI or the ones who are work and can afford it including their family [4]. The dues for PBI are the responsibility of the government; meanwhile, the non-PBI ones are responsible for their dues either paid by themselves or by their employer [4]. All active participants are guaranteed to earn the same benefits of health care in health facilities that are coordinated by BPJS.

JKN as a program has been a fresh air for Indonesians especially the poor or marginalized people who cannot afford healthcare before. There are "success story" of people who can have cancer or heart surgery for free, mothers for delivering babies for free, etc. However, we cannot pretend to be blind that there is still imperfectness in the implementation too. For instance, the bureaucracy that takes the immense patience of the participants, the undistributed of health personnel and the facilities itself, the minimum wage of health personnel, the access of JKN in a remote area, etc. Therefore, with the establishment of JKN in Indonesia, I argue that the government has tried to make the access to health care is more accessible for everyone, especially for the marginalized people. However, there are still several things inside the system itself that needs evaluation and obstacles from outside the system that needs to be overcome.

Second, the access to the minimum essential food (nutritionally adequate and safe) and third, the access to shelter, housing and sanitation and an adequate supply of safe drinking water. Indonesia is one of developing countries with increasing number of baby stunting and infectious disease in each year [5; 6]. It is believed that malnutrition is the grass root of this problem. There are many aspects involve; the quality of the foods, the quantity, and also the accessibility. The government has continuously approached this issue through its ministries. For instance, Ministry of Health has socialized the 'gizi seimbang' (balanced nutrition) program due to the concern that up to 2010 Indonesian people have proven not yet consumed nutritious and safe diet [5]. Bappenas (Badan Pembangunan Nasional: National Development Agencies) cooperated with World Food Program (WFP) also promote three programs; nutritious foods, food accessibility for the rural, and prevention of food disasters [7]. So does with shelter, adequate housing - sanitation, and safe drinking water programs. Government through its different ministries has promoted and socialized related programs. Not to mention, that these two components were also the goals of MDGs 2015 and SDGs 2030 which Indonesia actively promote and attempt to reach the goals. However, programs take times and an endless effort. UNICEF in 2012 has reported that diarrhea due to inadequate housingsanitation and safe drinking water was still the number 1 cause of toddlers' mortality in 2007 in Indonesia [8]. West Java, as the province with the highest record of most safe drinking water, even is still noted to have one out of three families not having such access [8]. UNICEF also reported that in 2012, Indonesia still lacks 26 million people living with adequate house-sanitation and safe drinking water to reach the MDGs 2015 in that aspect only. Therefore, it appears that Indonesia has attempted to fulfill such obligation, yet the obstacles have not been prevented and overcame well.

Fourth, the provision of essential drugs. Drugs undoubtedly play a crucial role in health spectrum. Generally speaking, what would we do if there are no drugs to cure or at least to prevent the illness? Thus, the provision and the management of it should be organized well. WHO Regional Advisor in Essential Drugs and Other Medicines, Kathleen A Holloway, reported that in general Indonesia has "an extensive health care system with substantial infrastructure, trained healthcare personnel, and good health indicators, but not in pharmaceutical concerning drug supply, selection, use, and coordination" [9]. In supply, for instance, the director of the pharmaceutical service of the Ministry of Health, stated that there was still 214 pharmaceutical companies in Indonesia when there should be thousands of it regarding the hundred billion people of Indonesians [10]. Also, since in 2000 Indonesia adopts decentralization system, it is difficult to supervise the use of drugs control in public use as there is no electronic drug inventory system. Meanwhile, this can be a measurement or 
evaluation of economic growth by looking at the use of drugs in Indonesia [9].

In use, for instance, WHO found that Indonesian doctors prescribed high polypharmacy, antibiotics, vitamins, and steroids which to some extent irrational number [9]. It can be influenced by many factors including the accessible and the affordable of the drugs itself. As we know, [9] BPJS has covered $66 \%$ of Indonesian citizens which this program uses generic drugs. It does not mean it is not good, but there should be a helpful system that makes drugs are not only affordable and accessible but also effective.

Indonesia also still lacks on pharmaceutical research and development and raw material infestation. There are many factors but what is being the grass root is the funding itself. For JKN program itself, Indonesia in 2016 still deficit up to 62,3 trillion Rupiah. If we can develop this field, the pharmaceutical industry in Indonesia will be developed, and it will press our dependency on import which will save our national budget. However, this can be overcome if the government more often cooperate with the private sector to fund this.

By looking at this stage, it appears that Indonesia has not fully committed to this aspect yet. Pharmaceutical industry market has grown up to $7,49 \%$ in the fourth quarter 2016 to 2017 [11], and the existence of generic drugs bring good news regarding accessible and affordable aspect, yet another element such as supply control, effective use, research and development, and funding still marginalized.

Fifth, the equitable distribution of all health facilities, goods, and services. This stage is a broad area of discussion. However, from the first to the fourth obligation, this research argues that distribution of all health facilities, goods, and services is still inequitable either regarding quality, quantity, or even the location distributions. The causes are complex and multilayered; from tangible things until policy decision. For example, the broadness area of Indonesia where the remote area is unreachable for the health personnel and facilities distribution. It is added by the lack of infrastructure and transportation to reach such place. It can also be from the minimum salary of the health personnel especially doctors, the funding for research and development on pharmaceuticals, etc. Thus, not even the equity, the equality itself still needs much attention. Therefore, to say that Indonesia has fulfilled its core minimum obligation is not yet successful, but the effort towards it also cannot be neglected and should be continuously assisted.

\section{CONCLUSION}

In conclusion, this article finds that first, right to health is complex and multilayered. We have seen how (for example in the second and third obligation) poverty influences the access to nutritious foods and shelter, adequate housingsanitation and safe drinking water and the other way around; how malnutrition can affect the health of the people which later influence their education and income for the long term. Therefore, to fulfill it, the attempt should be from the multidimensional aspect.

Second, this research concludes that the development of the right to health in Indonesia after two decades of Reformation is progressing considering the implementation of the programs that are in line with some aspects of the core minimum obligations of the state in ICESCR. However, obstacles have not been overcome well by the government. As it is mentioned before, issues such as bureaucracy, funding, infrastructure, the availability and the distribution of health personnel and facilities stand on the way of the right to health not only in Indonesia but globally.

Last, this article also discovers that even though the right to health is the obligation of the state to respect, protect, and fulfill it, yet the role of other stakeholders in its implementation will be so much helpful. It can be seen in the previous discussion that Indonesian government is aided by several international organizations in conducting the right to health programs. Even, individual who gives the space for the disabilities in Transjakarta bus is considered has helped the government in fulfilling this right.

\section{References}

[1] Human Rights Watch. (2017). World Report 2017: Indonesia Events of 2016. Retrieved from https://www.hrw.org/worldreport/2017/country-chapters/indonesia.

[2] World Health Organization. (2002). 25 Questions and Answers on Health and Human Rights. Health \& Human Rights Publication Series Issues No. 1.

[3] Office of the United Nations High Commissioner for Human Rights (OHCHR) \& World Health Organization (WHO). The Right to Health (Factsheet no. 31). Geneva: OHCHR.

[4] KementerianKesehatanRepublik Indonesia (Ministry of Health Republic of Indonesia). BukuPeganganSosialisasi: JaminanKesehatan (JKN) dalamSistemJaminanSosial Nasional (SJSN). Jakarta: Ministry of Health Republic of Indonesia.

[5] KementerianKesehatanRepublik Indonesia (Ministry of Health Republic of Indonesia). 
(2014). PedomanGiziSeimbang. Jakarta: Ministry of Health Republic of Indonesia.

[6] The World Bank. (2016). InvestasiNutrisiAnak Akan Membawa Indonesia MenujuKemakmuran. Retrieved from http://www.worldbank.org/in/news/opinion/20 16/11/28/investing-in-children-nutritionsupports-indonesia-on-a-path-to-prosperity.

[7] Bappenas (National Development Agencies). (2015). Kementerian PPN/Bappenas-World Food Program Bahasa Area KrusialPangandanNutrisi Indonesia. Retrieved from https://www.bappenas.go.id/id/beritadan-siaran-pers/kementerian-ppnbappenasworld-food-programme-bahas-area-krusialpangan-dan-nutrisi-indonesia/.

[8] UNICEF Indonesia. (2012). RingkasanKajian: Air Bersih, Sanitasi, \&Kebersihan. Retrieved from https://www.unicef.org/indonesia/id/A8 _B_Ringkasan_Kajian_Air_Bersih.pdf.

[9] Holloway, Kathleen A. (2011). Indonesia: Pharmaceuticals in Health Care Delivery. Retrieved from http://www.searo.who.int/entity/medicines/ind onesia_situational_analysis.pdf?ua $=1$.

[10] Medistiara, Yulida. (2016). Baru Ada 214 IndustriFarmasi di Indonesia, Kemenkes: HarusnyaRibuan. Retrieved from https://finance.detik.com/berita-ekonomibisnis/3336321/baru-ada-214-industri-farmasidi-indonesia-kemenkes-harusnya-ribuan.

[11] Dahwilani, Dani M. (2017). PeluangdanTantanganIndustriFarmasi di Indonesia 2017. Retrieved from https://ekbis.sindonews.com/read/1190701/34/ peluang-dan-tantangan-industri-farmasi-diindonesia-2017-1490187954. 